\title{
The impact of digital economy at the entrepreneurial capital
}

\author{
Oleg Ponomarev \\ TD "Semia" $L M T$ \\ Kaliningrad, Russia \\ obp969@mail.ru
}

\author{
Sergey Svetunkov \\ Graduate School of Business and Management \\ Peter the Great St.Petersburg Polytechnic University \\ St.Petersburg, Russia \\ sergey@svetunkov.ru
}

\begin{abstract}
In modern economics, ideas about entrepreneurial capital are diffuse. In the scientific literature, entrepreneurial capital is represented as something permanent. But over time, not only the types of activities of entrepreneurs change. External business conditions are changing. The skills and technologies that modern entrepreneurs use are changing. Consequently, under the influence of the digital economy, entrepreneurial capital must also change.
\end{abstract}

Keywords - capital, entrepreneurial capital, entrepreneurial spirit, entrepreneurial strength, potential, digital economy

\section{INTRODUCTION}

M. Weber believed that capitalism based on the constant assessment of revenue and costs has existed in most countries. According to M.Weber, capitalism is not a new phenomenon; countries have had this economic and political system at one period of their history or another. However, over time, it acquired a fundamental importance in the West whereas in other countries it did not take on such profound significance. In his book "The Protestant Ethic and the Spirit of Capitalism", M. Weber proved that the main feature of European capitalism is not the desire for profit or monetary gain since it has been typical of all people belonging to different social strata and in all countries. He believed that a desire for enrichment, entrepreneurship and monetary benefits, have nothing to do with capitalism as such. Waiters, doctors, coachmen, artists, prostitutes, civil servants, bribetakers, soldiers, robbers, crusaders, gamblers and beggars, i.e. "all sorts and conditions of men" at any time and in all countries of the world, feel the same desire for personal enrichment. "At present, under our political, legal, and trading institutions, with the business structure characteristic of our economy, this "spirit" of capitalism could, as we have said, be understood purely as a product that has adapted to its environment" [17].

The main difference between the emerging capitalism and the old archaic capitalism is not so much in how profits are made but in the spirit of West European capitalism. M.Weber introduced the concept of ethos for the designation of this new spirit. Discussing Benjamin Franklin's position in this respect, he wrote: "But the general thrust of his argument is that the ethos of modern capitalism - that is, its distinctive moral attitudes toward economic activity and work..."[17]

"The Protestant ethic and the spirit of capitalism" aroused significant research interest in the problem of the influence of religion on the character and success of a business. From the standpoint of our research, it is of interest that the very concept of the "spirit of capitalism" introduced into the economic science by M.Weber, motivated his followers to study its essence and to further develop the notion.

Of particular interest is a book by Werner Sombart "Bourgeois" (translated as The Quintessence of Capitalism), in which he introduced the concept of entrepreneurial spirit. W.Sombart, without disputing the existence of a 'capitalist spirit', describes several other types of spirit - the economic, petty-bourgeois, entrepreneurial, etc. "First we must trace the origin and growth of the capitalist spirit... There we dissect the whole into its component parts, and we shall turn our attention chiefly to two, the spirit of enterprise and the bourgeois spirit, which when united generated the capitalist spirit" [13]. This means that W.Sombart singled out the capitalist spirit as the basic one. It consists of two parts the entrepreneurial spirit and the philistine spirit. The entrepreneurial spirit is an integral part of the capitalist spirit. Expressing a hypothesis about the structure of the capitalist spirit consisting of two components - the philistine and entrepreneurial spirit - Sombart further analysed the development of the capitalist spirit as a phenomenon, which is common for all European and American countries in the New Age.

The concepts of "entrepreneurship", "capital", "entrepreneurial spirit" and "capitalist spirit" are so closely interconnected that they gave rise to several new notions in modern economics, one of which is the notion of entrepreneurial capital. Before moving on to the analysis of entrepreneurial capital, we need to understand what is understood by capital in general. Strange as it may seem, this is one of the concepts the most difficult to define in economics.

Lester D. Taylor, author of "Capital, Accumulation, and Money: An Integration of Capital, Growth, and Monetary Theory", admitted that he had studied the question of what capital was for 25 years and still failed to define it. The more books he read on the topic, the less clear it was for him. He recalled a conference in New Zealand and asking one of the prominent theoretical economists to give his definition of capital. The economist replied, "Oh, capital! That is the $\mathrm{K}$ that appears in the aggregate production function!" [14]. He defined capital just as a simple variable in the mathematical equation of the production function. 
L.Taylor came to the conclusion that instead of the word capital, another term - liquid capital - should be used. This is his translation of the Greek-Latin term 'myros', thereby demonstrating the fragility and vagueness of the boundaries of this fundamental concept.

At the heart of his interpretation of the concept, there is the following general principle: different terms should be used in sentences containing the word capital, for instance, financial capital, working capital, etc. They should be used exclusively in the meaning required by specific contexts, but as such "a single word, capital, cannot cover all contingencies of its use without proper qualification" [14].

Trying to uncover the essence of the term capital, Jacek Tittenbrun first examined such concepts as human capital, social capital and cultural capital. Only later did he go on to the classical description of the relations between property, capital and goods. He indicated that under capitalism many things, services and even relations are shaped as goods and therefore become part of capital [15]. He believed that everything involved in commodity-money circulation can be attributed to capital.

L.Balint and A.Jones, on the contrary, consider capital to be a single whole, consisting of several components: industrial capital (buildings and machines), human capital (knowledge, skills, experience and health), social capital (relations and institutions), and financial capital (monetary wealth), as well as natural capital [1, p.6]. Capital is the sum of these individual components.

"The concept of human capital tries to break the notion that capital is independent from man, considering things internalized as the elements of man as capital", says Wang [16, p.91]. Human capital is the development of a more general concept of capital. This development is predetermined by the fact that labour is included in the concept of capital., but human capital is not a primary component. After all, human capital is the most general concept characterizing labour as an industrial component. Human capital is, of course, a complex system, which also consists of individual elements.

Having reflected on the complex structure of the concept of capital and its components, Bourdieu came to the conclusion that there is another component - cultural capital [2]. Cultural capital, in turn, also consists of a set of elements. From this point of view, the emergence of a new concept - that of moral capital [16, p.93] is only logical. However, Bourdieu's interpretation of capital implied more complex and detailed relations between human, entrepreneurial and financial capital, and it also included social relations.

The concept of entrepreneurial capital was a logical extension of the attempts of different authors to apply the concept of capital to the description of different aspects of capitalism. Since the concept of capital has received so many different interpretations, we can foresee an even wider variation of definitions of the concept of entrepreneurial capital.

Modern Russian economists hold that entrepreneurial capital is an investment in enterprises, both new and existing ones. There are two types of investment:
1) direct investment - investment directly in machinery, equipment and other production factors;

2) portfolio investment - investments in stocks, bonds and other securities of foreign enterprises [10, p. 354]

Obviously, this definition of entrepreneurial capital is related to the fact that the author equals business and entrepreneurship. However, there is a significant difference between these two concepts. Business is the independent conduct of some economic activity whereas entrepreneurship is the kind of business, which is carried out for expanding and developing capital, which the entrepreneur has [11]. Therefore, the meaning of entrepreneurial capital does not cover all the assets that the entrepreneur attracts for his economic activities. Moreover, if we agree that entrepreneurial capital is the capital used by the entrepreneur, then it is not clear why the term 'capital' needs the attribute 'entrepreneurial'? After all, its difference from the capital of any other business becomes insignificant.

In their works on capital, Cooper, Gimeno-Gascon and Woo argue that capital consists of two components human capital and financial capital [5]. Therefore, in their opinion, entrepreneurial capital should be defined as a sum of human capital available to the entrepreneur and the attracted financial capital. The entrepreneur himself is of no importance and his personal properties do not affect the composition and size of entrepreneurial capital.

Other economists exploring human capital do not agree with this point of view. For example, a group of researchers who studied women's entrepreneurship note that the division into financial capital and non-financial capital, i.e. human capital that the entrepreneur has, is a mistake. In addition to human capital, there is also social capital, which has a considerable impact on the results and success of any business [4, p.187]. These authors consider entrepreneurial capital to be a separate component of capital and focus their attention on the relationship between gender capital, financial capital, and entrepreneurial capital.

The claim that entrepreneurial capital is a special form of production resource, determined, to a large extent, by the personal properties (characteristics) of the entrepreneur, has been questioned by many authors. This doubt is based on the fact that many entrepreneurs, including very successful ones, did not possess special knowledge and skills, which are indispensable components of human capital: "In many cases, investors rightly deny entrepreneurs capital because they lack the management skills necessary to grow and develop highgrowth businesses, with the expectation that investment in them would likely fail" [3, p.9].

Nevertheless, the interpretation of entrepreneurial capital as a special kind of capital does exist and is being developed. Erikson was among the first researchers who attempted to elaborate a conception of entrepreneurial capital, built on the dichotomy financial capital - non-financial capital [7]. It is the latter that is related to entrepreneurial capital, according to modern authors; it is "the physical, organizational, technological, human, cultural, social, and symbolic capital of business owners and their firms" [12, p. 150]. Unfortunately, we could not find any research works that would further concretise the concept of entrepreneurial capital among publications on entrepreneurship. 


\section{SYSTEM REPRESENTATION ON BUSINESS ENTREPRENEURSHIP}

In our opinion, the key to the definition of entrepreneurial capital is the indication of the fact that capital is used to gain profit. Marshall, the father founder of neoclassical economics, was the first to point out that the entrepreneur uses hired labour and (most often) borrowed capital [9]. His idea was supported by other economists, who came to the consensus that profit is a reward the entrepreneur gets for being able to combine labour and capital and for organising production and sales.

However, other actors of the economic system - almost any business person and not only entrepreneurs - use hired labour and borrowed capital. Therefore, it is necessary to find some other distinctive features inherent in entrepreneurial capital.

We will distinguish between two concepts: the capital used by the entrepreneur and entrepreneurial capital.The capital used by the entrepreneur is a combination of financial, tangible and intangible assets that the entrepreneur attracts for production. It is no different from the capital that is used in any other business.

Entrepreneurial capital is an element of the economic system, which is inherent only to the entrepreneur and to no one else. The basis of entrepreneurial capital is formed by entrepreneurial substance and entrepreneurial potential.

Entrepreneurial substance is a combination of entrepreneurial force and entrepreneurial abilities.The word combination 'entrepreneurial force' is rarely used in scientific literature.

Grau uses it as a certain alternative to the power of income: "If you use only the power of income in business and nothing else, you will receive income and pay much more for it if you use entrepreneurial force and the power of income " $[6$ D, c. 20]. Lu M. and Pan H. argue that "entrepreneurial force" reflects the strength of resources of the economic system" [8, p. 63].Since force, by definition, is a measure of the impact of other bodies and fields on the body in question, then entrepreneurial force should be considered by analogy as a measure of the influence of the entrepreneur on the economic system in which he works. In our opinion, the number of the entrepreneurial forces that make up the entrepreneurial substance should include: 1) the instinct of a millionaire; 2) will; 3) accuracy (precision); 4) curiosity; and 5) responsibility.

The terms 'entrepreneurial talent' and 'entrepreneurial abilities', which are parts of entrepreneurial substance, can be used provided we agree that entrepreneurship is not a craft, but an art. Only talented and capable individuals can create this kind of art.

Entrepreneurial abilities are a set of personal properties, qualities and skills, allowing the individual to organize a business, to identify and use the best combination of resources, to think outside the box and make non-standard decisions for extracting the maximum profit. This is the ability to correctly assess possible risks of making these decisions and to implement them. Entrepreneurial abilities are determined by age, gender, education and the experience of independent economic activities.
Since talent is an exceptional ability of a person that reveals itself and develops with experience and the acquisition of certain skills, then entrepreneurial talent is an exceptional entrepreneurial ability.

Generally speaking, every person has entrepreneurial abilities. As the history of the Russian economy of the 1990s shows, people having completely different life experience and belonging to different social strata were engaged in entrepreneurial activity. The economic reforms of the 1990s broke down the socioeconomic structure that had existed for decades. No wonder, many people ended up at the lower levels of the social hierarchy. They could break this social deadlock only through entrepreneurship. However, only talented entrepreneurs achieved significant success.

Entrepreneurial substance is the most important part of entrepreneurial capital. Entrepreneurial capital, being a productive force, is determined not only by entrepreneurial substance, but also by entrepreneurial potential. Entrepreneurial potential is an opportunity for an entrepreneur to do business and the conditions created for doing it.

If entrepreneurial substance is a set of properties inherent to an entrepreneur, then entrepreneurial potential is a result of some external impact, the environment where the entrepreneurial substance creates an opportunity (or lack of opportunities) to be engaged in entrepreneurial activity.

Entrepreneurial potential is determined by the openness and the readiness of the economy to start a new business, to create the infrastructure for this business and to form the attitude of society to business in general and entrepreneurship in particular, etc.

Thus, entrepreneurial capital consists of two interrelated parts:

1) a set of properties inherent only to the entrepreneur (entrepreneurial substance), and

2) a set of conditions and factors that allows a potential entrepreneur to make a decision to start an independent entrepreneurial activity (entrepreneurial potential).

Since entrepreneurial capital is a variable, it can be measured. Entrepreneurial capital will be different in different countries, and even in different regions of these countries. We propose to use two components of entrepreneurial capital - personal properties of the entrepreneur and the conditions imposed by the external environment - for the measurement of entrepreneurial capital.

Personal properties of the entrepreneur can be measured using a variety of sociological methods, the main method being that of a survey. Entrepreneurial substance can be represented as a system of five basic entrepreneurial forces - the instinct of a millionaire, will, accuracy (precision), curiosity and responsibility.

Entrepreneurial abilities, which also belong to entrepreneurial substance, can be measured and assessed using sociological surveys. Since methods of sociological research, including surveys, are well elaborated and studied, we will not dwell on them in more detail here. Rather, we 
reflect on the second part of entrepreneurial capital related to entrepreneurial potential.

It is here that we see a link between entrepreneurial spirit, which was mentioned at the beginning of the article, and entrepreneurial capital. The presence of a special entrepreneurial spirit in society generates opportunities for people having entrepreneurial substance to engage in entrepreneurship. It is the entrepreneurial potential (determined by the entrepreneurial spirit in society), that contributes to the formation of entrepreneurial capital.

In any society, there have always been people having entrepreneurial substance. However, entrepreneurial capital was not always available since external conditions did not allow entrepreneurial potential to be formed. Only the capitalist spirit created conditions for the formation of entrepreneurial spirit, and together with it, entrepreneurial capital.

Entrepreneurial potential, that is, the ability of an entrepreneur to participate in economic activity, is determined by the presence or absence of the necessary resources, or in other words, the availability of these resources. In economics, for more than a hundred years there has been an opinion that the entrepreneur manages two types of resources: capital (financial resources) attracted for business, and labour force that the entrepreneur hires in the market. But this is only a strong simplification. [18]

Today, when a new economic paradigm, the digital economy, is being formed, information is becoming the most important productive resource. Economists have been talking about the importance of information as a productive resource since the 1960s. Philosophers have started to assert that information is a form of the existence of matter. We live in an era of the growing influence of the digital economy on all aspects of life. This is the era of information. The possession of information today is akin to owning the world. Many different organisations, companies and individuals gather, assess and manage information. Psychologists and sociologists talk about the information overload of the digital age, which is perceived as a distracting and uncontrollable factor, eroding reality.

A few decades ago, people seemed to manage information; at least they had the opportunity to receive it in manageable quantities. Today, e-mail spam, notifications, instant messages, microblogging and social network posts, along with thousands of articles in numerous media, create an oversupply of information. In an attempt to perceive and digest it, people become less concentrated and their attention becomes distributed. This poses a certain paradox - the more information the person gets, the more uncertainty is created. The essence of the paradox is that, by definition, information is a measure to eliminate uncertainty. This overabundance of information forces the individual to assess a plethora of options in decision-making, which is a difficult task since the human brain cannot quickly process large data arrays. If the entrepreneur get some information about a single fact or an event, he can easily understand it and give it a very careful assessment. If he gets information about two events occurring simultaneously, he can still easily process it and make the right decision. But in the conditions of the overabundance of information, the entrepreneur is not able to react promptly and make the right choice; he is not often able to make any decision at all. Therefore, information is the most important resource that any modern entrepreneur uses in his entrepreneurial activities.

In the digital economy, when production implies the use of information technologies, it becomes increasingly clear that time is the most valuable resource for business. It is the most important resource available to the entrepreneur. To have time to make an important decision before everyone else and to implement it in an effort to maximize profit - this is when entrepreneurial substance applied to this resource becomes obvious and is used. According to researchers studying entrepreneurship, it is when the entrepreneur controls time that he develops the ability to take risks.

Entrepreneurial risk is a situation where: any event may develop in multiple ways; the decision may lead either to a loss (or other negative consequences), or to a significant gain; the entrepreneur intuitively assesses the quantitative results of the decision made; the decision made concerns the interests of several people. To make a decision in a risky situation is an important step that only the one who has completely mastered the talent of using time as a resource can dare to make.

The modern world gives every businessperson the opportunity to use multiple and diverse technologies. This variety of technologies implies the need to choose one of them. Today, technologies have become a valuable resource used by the entrepreneur. Each technology has its own advantages and disadvantages. Technology developers enthusiastically demonstrate the advantages of their technology when promoting it. However, they prefer either to be silent about potential pitfalls, or to report them in small print. It is difficult to cope with a large amount of information on technological development. To do this, the individual must either have encyclopaedic knowledge, or a phenomenal memory. As a rule, the entrepreneur has neither. Instead, he uses that part of his entrepreneurial substance, which can be called the instinct of a millionaire. This instinct allows him almost instantly, bypassing the numerous stages of reasoning, comparisons and preliminary choices, to 'feel' the potential of the production technology, which he chooses as the key one.

Regardless of the fact what it is - conveyor, kanban, lean production, self-service in trade, automatic delivery rewards, robotisation or transition to IFRS, employees tend to avoid new technologies since their implementation is always associated with additional labour, time and effort. Only by displaying his will power in this new, unknown form of business, the entrepreneur can achieve a real breakthrough. This is technological management of the product in the costquality ratio.

The entrepreneur of the engineering type is a priori engaged in the technological development of his business. Entrepreneurs of other psychological types often face a dilemma: either to systematise and strictly regulate their business, or to create a free and comfortable environment in their company. In industrial companies, entrepreneurs usually form a classical vertical S-system, while in innovative companies they follow the path of a creative Penvironment. Having chosen the key technology, the entrepreneur has to decide when he has to invest into 
technological upgrades not to miss a new technological pattern or a trend.

In 1994, O. Ponomarev, one of the co-authors of the article, was a master student of professor Olivier Badot. In his course on neo-marketing for master students, Olivier Badot claimed that for a marketing specialist there are two important words: la veille (wakefulness, alertness) and le reniflage (sniffing). Since then, the speed of technological change has grown exponentially. Opportunity knocks only once and the one, who misses it, misses it forever. It is a well-known fact that in the 1980s, Steve Jobs had a vision of the future iPad, but it took him more than 20 years to implement the idea, buying and developing the technologies he needed. Technology equals progress - differentiation and cost reduction.

The entrepreneur of today is a versatile person. He has to constantly make the most diverse and complex decisions. Technological solutions produced by narrow specialists cannot be adopted without proper consideration and foreseeing their consequences for the entire business. The main competence of the entrepreneur is his conscious competence in the vital areas for his business. New technologies cannot be a panacea for all ills, and excessive loans can certainly stifle even a most promising business. Quite often, opting for a traditional technology can save from serious problems.

One way of saving resources is to buy expensive technologies at a lower price during a crisis. Facing the threat of losing the market, the entrepreneur is often obliged to make a tough decision on the termination of a part or even the whole technology project and either moving his team and capital to a new sector or launching a new project. This is the strategy of many large corporations. They are constantly looking for breakthrough technologies and transfer resources there.

\section{CONCLUSION}

Thus, entrepreneurial substance consisting of entrepreneurial abilities, five entrepreneurial forces and entrepreneurial potential, defined as a measure of the availability of five core resources, constitute entrepreneurial capital, which can now be assessed at any level of business hierarchy.

Entrepreneurs who actively use the tools and methods of the digital economy increase their entrepreneurial capital. Those entrepreneurs who ignore the new digital economy, have a smaller amount of entrepreneurial capital. They cannot achieve the impressive decisions they seek.

\section{REFERENCES}

[1] Balint L., Jones A. Natural Capital and Intergovernmental SciencePolicy Platform on Biodiversity and Ecosystem Services // Debating Nature's Value: The Concept of 'Natural Capital'. Springer, 2019. Pp $5-17$.

[2] Bourdieu P. Distinction: A Social Critique of the Judgement of Taste. Harvard University Press, 1984. 613 p.

[3] Buss T.F. Capital, Emerging High-growth Firms and Public Policy: The Case Against Federal Intervention. Greenwood Publishing Group, 2001. 237 p.

[4] Candida G. B., Bruin A., Gatewood E.J., Henry C. Women Entrepreneurs and the Global Environment for Growth: A Research Perspective. Edward Elgar Publishing, 2010. 360 p

[5] Cooper A.C., Gimeno-Gascon F.J, Woo C.Y. Initial human and financial capital as predictors of new venture performance // Journal of Business Venturing, 1994, 9, p.371-395.

[6] Grau D. Buying, Selling, and Valuing Financial Practices, + Website: The FP Transitions M\&A Guide. John Wiley \& Sons, 2016. 320 p.

[7] Erikson T. Entrepreneurial Capital: The Emerging Venture's Most Important Asset and Competitive Advantage Journal of Business Venturing, 2002. Vol. 17, p. 275-290.

[8] Lu M., Pan H. Government-Enterprise Connection: Entrepreneur and Private Enterprise Development in China. Singapore: Springer, 2015. 168 p

[9] Marshall A. Principles of Economics: Unabridged Eighth Edition. Cosimo, Inc., 2009. 740 p.

[10] Okeanova Z. K. Economic theory: a textbook. M .: Dashkov and Co., 2012. 652 p. [Z. K. Ekonomicheskaya teoriya: uchebnik. M.: Dashkov i Ko, 2012. 652 s.].

[11] Ponomarev O.B., Svetunkov S.G. Dynamic approach to the analysis of the essence of entrepreneurship // Revista ESPACIOS. 2018, vol. $39\left(\mathrm{~N}^{\circ} 50\right)$

[12] Sethna Z., Jones R., Harrigan P. Entrepreneurial Marketing: Global Perspectives. Emerald Group Publishing, 2013. 320 p.

[13] Sombart W. The Quintessence of Capitalism: A Study of the History and Psychology of the Modern business man. Routledge / Thoemmes Press, 1998. 395 p.

[14] Taylor L. D. Capital, Accumulation, and Money: An Integration of Capital, Growth, and Monetary Theory. Springer Science \& Business Media, 2010. 278 p.

[15] Tittenbrun J. Concepts of Capital: The Commodification of Social Life. Routledge, 2017. 272 p

[16] Wang Xiaoxi. On Moral Capital. Springer, 2015. 266 p.

[17] Weber M. The Protestant Ethic and the Spirit of Capitalism: and Other Writings, Penguin, 2002. 464 p.

[18] Demidenko, D.S., Kulibanova, V.V., Maruta, V.G. Using the principles of "digital economy" in assessing the company's capitalization (2018) pp. 6087-6091. 